\title{
木造住宅の建設時の $\mathrm{CO}_{2}$ 排出量削減を目指した対策と評価 在来工法による木造戸建住宅の環境負荷予測に関する研究 その 3
A COUNTERMEASURE AND ASSESSMENT FOR REDUCING $\mathrm{CO}_{2}$ EMISSIONS CONNECTED WITH THE CONSTRUCTION OF DETACHED WOODEN HOUSES

Predicting the environmental impact of constructing detached wooden houses by conventional methods Part 3

\author{
高村秀紀*, 浅野良晴** \\ Hideki TAKAMURA and Yoshiharu ASANO
}

\begin{abstract}
This paper focuses on how to reduce $\mathrm{CO}_{2}$ emissions regarding construction materials. We compared section by section the amount of $\mathrm{CO}_{2} \mathrm{emissions} \mathrm{from}$ the four different houses. Next, we made an improved plan that took away the first floor that was constructed with reinforced concrete, as well as the interior decorations which emitted less $\mathrm{CO}_{2}$ during their factory production. The following results were obtained.

1) We determined which sections of the four houses had less construction waste. We determined which sections of the four houses emitted less $\mathrm{CO}_{2}$ during their production.

2) The total amount of $\mathrm{CO}_{2}$ emissions per floor from construction materials is $318.8 \mathrm{~kg}-\mathrm{CO}_{2} / \mathrm{m}^{2} \sim 498.1 \mathrm{~kg}-\mathrm{CO}_{2} / \mathrm{m}^{2}$.

3) The proposed countermeasure that took away the first floor reduced $\mathrm{CO}_{2}$ emissions by $15.7 \times 10^{3} \mathrm{~kg}-\mathrm{CO}_{2}$, a decrease of $30.4 \%$.The proposed countermeasure that used the interior decorations, which emitted less $\mathrm{CO}_{2}$ during their factory production, reduced $\mathrm{CO}_{2}$ emissions by $5.1 \times 10^{3} \mathrm{~kg}-\mathrm{CO}_{2}$, a decrease of $9.9 \%$.The countermeasure that the authors described in their improved plan reduced $\mathrm{CO}_{2}$ emissions by $20.8 \times 10^{3} \mathrm{~kg}-\mathrm{CO}_{2}$, a decrease of $40.3 \%$.
\end{abstract}

Keywords : detached wooden houses, construction stage, measurement survey, reducing $\mathrm{CO}_{2}$ emissions 木造戸建住宅, 建設時, 実測調査, $\mathrm{CO}_{2}$ 排出量削減

\section{1.はじめに}

住宅分野における $\mathrm{CO}_{2}$ 排出量削減は重要な課題となっている。住 宅の $\mathrm{LCCO}_{2}$ に着目すると住宅は長期にわたり使用されるため、住宅 運用時のエネルギー消費に起因する $\mathrm{CO}_{2}$ 排出量の占める割合が多く なる。そのため、住宅運用時のエネルギー消費量に関する調查研究 や削減方法に関寸る研究が多数報告されている例えば 1) 3)。一方、住 宅建設に起因寸る $\mathrm{CO}_{2}$ 排出量が我が国の $\mathrm{CO}_{2}$ 排出量の総量に占める 割合は $5.2 \%$ と推計されており ${ }^{4)}$ 、決して無視することができないこ とから、住宅建設に起因する $\mathrm{CO}_{2}$ 排出量の削減方法について早急に 検討する必要がある。しかしながら、住宅建設時の $\mathrm{CO}_{2}$ 排出量削減 に対する研究は未だ少ないのが現状である。

建設時の $\mathrm{CO}_{2}$ 排出量に着目した研究として、横山ら ${ }^{5)}$ は低資源消 費型の事務所ビルを提案し、建物のライフサイクルにおける資源消 費量について従来建物との比較検討を詳細に行っている。しかしな

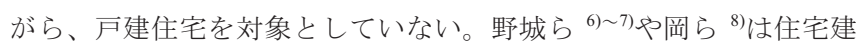
設時に投入される資材重量から住宅建設時の $\mathrm{CO}_{2}$ 排出量を詳細に算 出している。しかしながら、資材重量を図面や見積書から算出して おり、実際の投入量との比較を行っていない。近田ら ${ }^{9}$ は工業化住 宅を対象に構成部材に関する詳細な実態調査を行い、これに基づき
設計時に活用できる $\mathrm{CO}_{2}$ 排出量の簡易推計法を作成している。 本研究は在来工法による木造戸建住宅の建設時の $\mathrm{CO}_{2}$ 排出量の削 減方法を検討することを目的としている。この目的に対して、既報 10)では長野市内に建設された 1 階部分を RC 造とし、2・3 階部分を

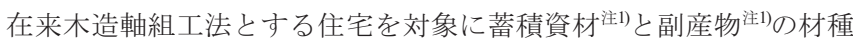
と重量の実測調查を行い、対象住宅の蓄積資材注1) と副産物注1)の重量 の実態を明らかにした。そして、環境負荷評価指標として蓄積資材 注1) と副産物主1)の重量と $\mathrm{CO}_{2}$ 排出量の床面積あたりの值を整理した。 さらに前報 ${ }^{11)}$ では、既報 ${ }^{10)}$ の住宅を含む 4 棟の木造住宅を対象に、 設計時において設計図書から算出した資材重量（以下、積算重量） と施工時における資材の実測重量の比較を基礎と躯体、屋根、外壁 を構成する資材について行った。そして、日本建築学会公表の $\mathrm{CO}_{2}$ 排出原単位 ${ }^{4}$ を積算重量と実測重量に乗じて $\mathrm{CO}_{2}$ 排出量を算出し、 床面積あたりの $\mathrm{CO}_{2}$ 排出量の差を明らかにした。そして、実測重量 に基づき算出した $\mathrm{CO}_{2}$ 排出量を積算重量に基づき算出した $\mathrm{CO}_{2}$ 排出 量から算出するための係数を整理した。

住宅建設時の $\mathrm{CO}_{2}$ 排出量削減のための検討事項として、(1)用途が 無い部位を見直し、適切な用途計画を行い、経済設計を行うことに よる使用資材の削減、(2)工事別の使用資材の見直し、(3)端材の削減
* 信州大学工学部建築学科, 信州大学山岳科学総合研究所 助教・博士 (工学)

** 信州大学工学部建築学科, 信州大学山岳科学総合研究所 教授・工博
Assistant Prof., Dept. of Architecture, Faculty of Engineering, Shinshu University and Institute of Mountain Science, Shinshu University, Dr. Eng.

Prof., Dept. of Architecture, Faculty of Engineering, Shinshu University and Institute of

Mountain Science, Shinshu University, Dr. Eng. 


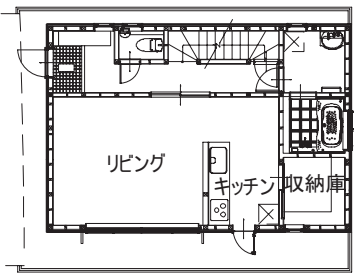

図 1 1 階平面図（住宅 A）

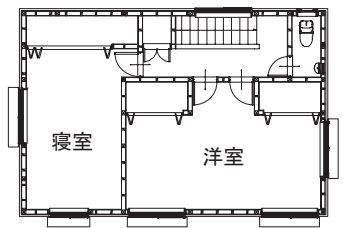

図 22 階平面図（住宅 A）

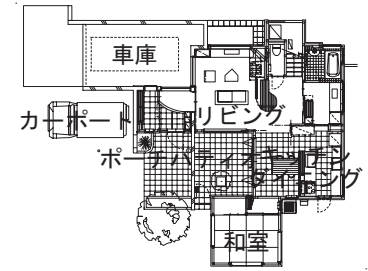

図 31 階平面図（住宅 B）

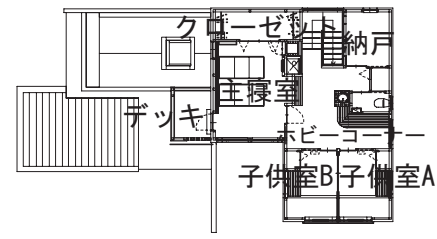

図 4 2 階平面図（住宅 B）
が考えられる。そのため本論文は前報 ${ }^{11) て ゙ ~}{ }^{2}$ 報告した 4 棟の住宅に対 して、実測した蓄積資材注1) と副産物 事別に整理し、比較した。そして、日本建築学会公表の $\mathrm{CO}_{2}$ 排出原 単位 ${ }^{4)}$ を蓄積資材注1) と副産物注1)の実測重量に乗じて $\mathrm{CO}_{2}$ 排出量を算 出し、工事別に延床面積あたりの $\mathrm{CO}_{2}$ 排出量を整理し、比較した。 さらに、工事別の比較結果を基に部位と使用資材の見直しを行った。 特に、住宅 A の 1 階部分は積雪対策として施主の個別事情により計 画、設計された部位であり、近年の積雪、降雪状況では利用されて いない空間となっている。施主が要望する個別事情が必要なものか 否か計画段階で十分に検討し、適切な用途計画を行うことで経済設 計が可能となる。これにより、使用される資材が削減され、住宅建 設時の $\mathrm{CO}_{2}$ 排出量削減につながると考える。よって、用途を見直す ことによる住宅建設時の $\mathrm{CO}_{2}$ 排出量削減効果を定量化した。次に、 使用する内装材を $\mathrm{CO}_{2}$ 排出原単位の小さい資材に変更し、 $\mathrm{CO}_{2}$ 排出 量の削減量を算出した。そして、部位と使用資材を見直すことによ る住宅建設時の $\mathrm{CO}_{2}$ 排出量の削減量を明らかにした。

\section{2. 対象建物概要}

対象建物 4 棟はいずれも在来木造軸組工法である。住宅 A は延床 面積 $162.0 \mathrm{~m}^{2}$ で高床式基䃈（RC 造部の床面積 : $54.0 \mathrm{~m}^{2}$ ）を有する 3 階建の住宅である。住宅 B は延床面積 $195.3 \mathrm{~m}^{2}$ で一部 $\mathrm{RC}$ 造の車庫 （RC 造部の床面積：22.1 $\mathrm{m}^{2}$ ）を有する 2 階建の住宅である。また、 住宅 C は延床面積 $138.6 \mathrm{~m}^{2}$ の 2 階建、住宅 D は延床面積 $163.6 \mathrm{~m}^{2}$ の 2 階建の住宅である。図 1 図 8 に住宅 A〜住宅 D の平面図を示 す。また、表 1 に住宅 A〜住宅 D の建物概要を示す。

\section{3. 蓄積資材重量と副産物重量の実測調査概要}

建設現場で着工から竣工までの全ての蓄積資材重量と副産物重量 の実測調查を行った。蓄積資材注1)については建設現場に納入される 都度、計測者が台ばかりを用いて計測した。副産物注りについては所 定の場所に保管し、ある程度まとまった段階で計測者が材種を確認 し、材種毎に重量を計測した。実測調查の詳細については前報 ${ }^{11)} に$ 記載されているため本論文では省略する。

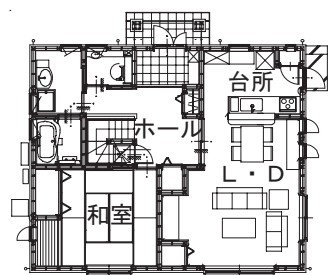

図 51 階平面図（住宅 C)

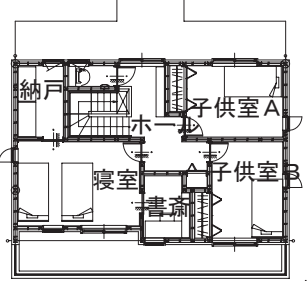

図 62 階平面図 (住宅 C)

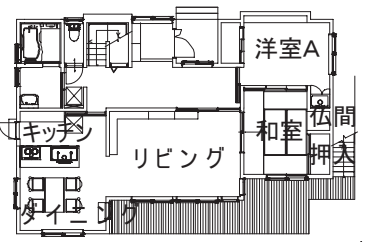

図 7 1 階平面図（住宅 D)

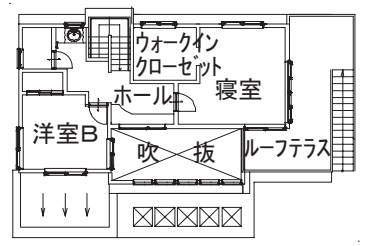

図 8 2 階平面図（住宅 D)

表 1 建物概要

\begin{tabular}{|c|c|c|c|c|}
\hline & 住宅 A & 住宅 B & 住宅 C & 住宅 D \\
\hline 延床面積 $\left[\mathrm{m}^{2}\right]$ & 162.0 & 195.3 & 138.6 & 163.6 \\
\hline $\begin{array}{l}1 \text { 階延床面積 } \\
{\left[\mathrm{m}^{2}\right]}\end{array}$ & 54.0 & 125.5 & 76.6 & 91.9 \\
\hline $\begin{array}{l}2 \text { 階延床面積 } \\
{\left[\mathrm{m}^{2}\right]}\end{array}$ & 54.0 & 69.7 & 59.3 & 71.7 \\
\hline 階高[m] & 2.4 & $2.1 \sim 3.9$ & $2.4 \sim 2.5$ & $2.2 \sim 3.7$ \\
\hline 外壁面積 $\left[\mathrm{m}^{2}\right]$ & 171.0 & 235.2 & 154.5 & 218.0 \\
\hline 屋根面積 $\left[\mathrm{m}^{2}\right]$ & 75.0 & 109.1 & 141.0 & 103.0 \\
\hline 使用断熱材 & $\begin{array}{l}\text { グラスウー } \\
\text { ル }\end{array}$ & $\begin{array}{l}\text { グラスウー } \\
\text { ル、押出法ポ } \\
\text { リスチレン } \\
\text { フォーム保 } \\
\text { 温板、ロック } \\
\text { ウール、ポリ } \\
\text { エチレンフ } \\
\text { オーム保温 } \\
\text { 板、硬質ウレ } \\
\text { タンフォー } \\
\text { ム保温板 }\end{array}$ & $\begin{array}{l}\text { 押出法ポリ } \\
\text { スチレンフ } \\
\text { オーム保温 } \\
\text { 板 }\end{array}$ & $\begin{array}{l}\text { 押出法ポリ } \\
\text { スチレンフ } \\
\text { オーム保温 } \\
\text { 板 }\end{array}$ \\
\hline $\begin{array}{l}\text { 気密層の有 } \\
\text { 無 }\end{array}$ & 無 & 無 & 有 & 有 \\
\hline 開口部 & $\begin{array}{l}\text { プラスチッ } \\
\text { ク金属複合 } \\
\text { サッシ、ペア } \\
\text { ガラス }\end{array}$ & $\begin{array}{l}\text { プラスチッ } \\
\text { ク金属複合 } \\
\text { サッシ、ペア } \\
\text { ガラス }\end{array}$ & $\begin{array}{l}\text { プラスチッ } \\
\text { クサッシ、ペ } \\
\text { アガラス }\end{array}$ & $\begin{array}{l}\text { プラスチッ } \\
\text { クサッシ、ペ } \\
\text { アガラス }\end{array}$ \\
\hline 外壁仕上げ & $\begin{array}{l}\text { 窯業系サイ } \\
\text { ディング }\end{array}$ & $\begin{array}{l}\text { モルタル荒 } \\
\text { 壁仕上げ }\end{array}$ & $\begin{array}{l}\text { 窯業系サイ } \\
\text { ディング }\end{array}$ & $\begin{array}{l}\text { 窯業系サイ } \\
\text { ディング }\end{array}$ \\
\hline 屋根仕上げ & $\begin{array}{l}\text { ガルバリウ } \\
\text { ム鋼板 }\end{array}$ & $\begin{array}{l}\text { ガルバリウ } \\
\text { ム鋼板 }\end{array}$ & 瓦 & $\begin{array}{l}\text { ガルバリウ } \\
\text { ム鋼板、瓦 }\end{array}$ \\
\hline 内装（壁） & $\begin{array}{l}\text { 塩化ビニル } \\
\text { 製クロス }\end{array}$ & 珪藻土 & $\begin{array}{l}\text { 塩化ビニル } \\
\text { 製クロス }\end{array}$ & $\begin{array}{l}\text { 塩化ビニル } \\
\text { 製クロス }\end{array}$ \\
\hline 内装（床） & $\begin{array}{l}\text { 複合フロー } \\
\text { リング }\end{array}$ & $\begin{array}{l}\text { 複合ブロー } \\
\text { リング }\end{array}$ & $\begin{array}{l}\text { 複合ブロー } \\
\text { リング }\end{array}$ & $\begin{array}{l}\text { 複合フロー } \\
\text { リング (一部 } \\
\text { 無垢) } \\
\end{array}$ \\
\hline 暖房方式 & $\begin{array}{l}\text { PTC 電気床 } \\
\text { 暖房 } \\
\text { エアコン }\end{array}$ & $\begin{array}{l}\text { ヒートポン } \\
\text { プ式温水床 } \\
\text { 暖房、蓄熱式 } \\
\text { 床暖房、暖炉 }\end{array}$ & $\begin{array}{l}\text { 太陽熱温水 } \\
\text { 暖房、灯油ボ } \\
\text { イラーによ } \\
\text { る温水ルー } \\
\text { ムヒーター }\end{array}$ & $\begin{array}{l}\text { 蓄熱式電気 } \\
\text { 暖房 }\end{array}$ \\
\hline $\begin{array}{l}\text { 断熱材施工 } \\
\text { 部位 }\end{array}$ & 床、壁、天井 & $\begin{array}{l}\text { 床(一部基 } \\
\text { 礎)、壁、天 } \\
\text { 并 (一部屋 } \\
\text { 根) }\end{array}$ & $\begin{array}{l}\text { 基礎（立上り } \\
\text { 部と底盤）、 } \\
\text { 壁、天井 }\end{array}$ & $\begin{array}{l}\text { 基礎 (立上り } \\
\text { 部)、壁、屋 } \\
\text { 根 }\end{array}$ \\
\hline $\begin{array}{l}\text { 勝手口周辺 } \\
\text { のコンクリ } \\
\text { ート敷設 }\end{array}$ & 無し & 有り & 無し & 無し \\
\hline 平面形状 & 単純な矩形 & $\begin{array}{l}\text { 単純な矩形 } \\
\text { ではない }\end{array}$ & 単純な矩形 & 単純な矩形 \\
\hline $\begin{array}{l}\text { サッシの搬 } \\
\text { 入経路 }\end{array}$ & 販社経由 & 販社経由 & $\begin{array}{l}\text { メーカー直 } \\
\text { 送 }\end{array}$ & 販社経由 \\
\hline 特記事項 & $\begin{array}{l}1 \text { 階が RC 造 } \\
\text { 高床式住 } \\
\text { 宅。 }\end{array}$ & $\begin{array}{l}\text { RC 造車庫を } \\
\text { 有する。延床 } \\
\text { 面積と } 1 \text { 階面 } \\
\text { 積が最大。総 } \\
2 \text { 階ではなな } \\
\text { い。外壁面積 } \\
\text { が最大。 }\end{array}$ & $\begin{array}{l}\text { 太陽熱利用 } \\
\text { 給湯暖房を } \\
\text { 有する。 }\end{array}$ & $\begin{array}{l}\text { 壁体内通気 } \\
\text { 工法。小屋裏 } \\
\text { に電動ファ } \\
\text { ン、電動で開 } \\
\text { 閉する床下 } \\
\text { ダンパーを } \\
\text { 有する。 }\end{array}$ \\
\hline
\end{tabular}




\section{4. 工事別の実測調査結果}

\section{1 工事区分}

蓄積資材注1) と副産物注1)の材種と重量の実測調查結果を工事区分ご とに整理し、4 棟の住宅に対して比較を行った。比較にあたり工事 区分を次の 9 区分に分類した。分類方法は木造住宅の積算に関寸る 文献 ${ }^{21) ~ 25)}$ を参考に区分した。なお、住宅 B における車庫工事に要 する資材は基礎工事に要する資材と一緒に搬入され、区分が困難で あったため基䃈工事に分類した。各工事における主な資材は以下の 通りである。

(1) 基礎工事 : 型枠、鉄筋、アンカーボルト、セパレータ、防湿シ 一ト、砕石、コンクリート等

(2) 躯体工事 : 集成材、端柄材注 2)、合板、構造用金物等

(3) 屋根工事 : ガルバリウム鋼板、釷、ビス、アスファルトルーフ イング、繊維板等

(4) 外壁工事: 水切り、サイディング接合金物、サイディング、砂、 セメント、シーリング剤等

(5) 内装工事: フローリング、造作材、建具金物、釘、ビス、壁紙、 石膏ボード、接着剤、畳等

(6) 開口部工事 : サッシ、ガラス、シーリング剤等

(7) 断熱・気密工事 : 押出法ポリスチレンフォーム保温板、現場発 泡ウレタン、気密シート、気密テープ、ロックウール、グラス ウール等

(8) 設備工事: 給水管、給水管継ぎ手、ボルト、蛇口、塩ビ管、塩 ビ管継ぎ手、架橋ポリエチレン管、コンクリートます、自然冷 媒ヒートポンプ式給湯器、太陽熱給湯器、小屋裏に設置するフ アン等

(9) 外構工事 : フェンス、コンクリート、砕石等

\section{2 蓄積資材重量の工事別の比較}

延床面積あたりの蓄積資材重量を工事別に比較した結果を表 2 に 示す。基礎工事では住宅 B の延床面積あたりの蓄積資材重量が最大 となった。これは、1 階の面積が他の住宅より大きいため基礎に使 用される資材重量が多いことや砕石を蓄熱材として使用しているた めである。また、車庫部分の資材も含まれているためである。躯体 工事では住宅 C の延床面積あたりの蓄積資材重量が最大となった。 これは、住宅 Cの製材の使用量が他の住宅に比べて多かったためで ある。屋根工事では住宅 C の延床面積あたりの資材重量が最大とな った。これは住宅Cの屋根材が比重の大きい瓦であったためである。 内装工事では住宅 $\mathrm{A} の$ 延床面積あたりの蓄積資材重量が最小となっ た。これは、住宅 $\mathrm{A}$ の 1 階部分が RC 造の高床部分であり、内装仕 上げをしていないため延床面積あたりの值が最小となった。また、 住宅 D の延床面積あたりの資材重量が最大となった。これは、住宅 D の石膏ボードの使用量が多かったためである。開口部工事でも住 宅 $\mathrm{A}$ が最小となっているがこれは 1 階部分の開口部が少ないためで ある。他の 3 棟の住宅に大きな差はない。断熱工事では、住宅 C の 延床面積あたりの蓄積資材重量が最大となった。これは、断熱仕様 が他の住宅よりも良く、押出法ポリスチレンフォーム保温板の使用 量が多かったためである。設備工事では住宅 C と住宅 D の延床面積 あたりの資材重量が大きくなった。住宅 C は太陽熱給湯器などの設 備が多いためであり、住宅 D では小屋裏に設置されたファンや電動 で開閉する床下ダンパーなどの設備があるためである。外構工事で
表 2 延床面積あたりの蓄積資材重量の比較

\begin{tabular}{|l|r|r|r|r|}
\hline 工事区分 & $\begin{array}{c}\text { 住宅 } \\
\left(\mathrm{kg} / \mathrm{m}^{2}\right)\end{array}$ & $\begin{array}{c}\text { 住宅B } \\
\left(\mathrm{kg} / \mathrm{m}^{2}\right)\end{array}$ & $\begin{array}{c}\text { 住宅C } \\
\left(\mathrm{kg} / \mathrm{m}^{2}\right)\end{array}$ & $\begin{array}{c}\text { 住宅D } \\
\left(\mathrm{kg} / \mathrm{m}^{2}\right)\end{array}$ \\
\hline \hline 基礎 & 875.4 & $1,053.5$ & 458.4 & 568.7 \\
\hline 躯体 & 53.3 & 73.5 & 114.2 & 80.4 \\
\hline 屋根 & 6.6 & 5.6 & 54.9 & 29.8 \\
\hline 外壁 & 13.0 & 15.2 & 23.3 & 17.4 \\
\hline 内装 & 35.5 & 45.4 & 49.4 & 52.4 \\
\hline 開口部 & 2.5 & 7.2 & 6.5 & 7.3 \\
\hline 断熱・気密 & 2.5 & 4.1 & 5.7 & 4.0 \\
\hline 設備 & 8.6 & 11.5 & 17.7 & 22.2 \\
\hline 外構 & 29.6 & 267.9 & 92.7 & 22.7 \\
\hline \hline 合計 & $1,027.2$ & $1,484.0$ & 822.7 & 805.0 \\
\hline
\end{tabular}

表 3 延床面積あたりの副産物重量の比較

\begin{tabular}{|c|c|c|c|c|c|c|c|c|}
\hline 住宅 & \multicolumn{2}{|c|}{ 住宅A } & \multicolumn{2}{|c|}{ 住宅B } & \multicolumn{2}{|c|}{ 住宅C } & \multicolumn{2}{|c|}{ 住宅D } \\
\hline & $\begin{array}{c}\text { 重量 } \\
\left(\mathrm{kg} / \mathrm{m}^{2}\right)\end{array}$ & $\begin{array}{l}\text { 端材の } \\
\text { 割合 }(\%)\end{array}$ & $\begin{array}{c}\text { 重量 } \\
\left(\mathrm{kg} / \mathrm{m}^{2}\right)\end{array}$ & \begin{tabular}{|l|} 
端材の \\
割合 $(\%)$
\end{tabular} & $\begin{array}{c}\text { 重量 } \\
\left(\mathrm{kg} / \mathrm{m}^{2}\right)\end{array}$ & \begin{tabular}{|l|} 
端材の \\
割合 $(\%)$
\end{tabular} & $\begin{array}{c}\text { 重量 } \\
\left(\mathrm{kg} / \mathrm{m}^{2}\right)\end{array}$ & \begin{tabular}{|l} 
端材の \\
割合 $(\%)$
\end{tabular} \\
\hline \begin{tabular}{|l|l} 
基礎 \\
\end{tabular} & 1.6 & 84.2 & 6.7 & 96.0 & 0.7 & \begin{tabular}{r|}
45.5 \\
\end{tabular} & 0.3 & 71.5 \\
\hline 躯体 & 2.7 & 95.8 & 10.0 & 98.6 & 5.3 & 97.4 & 7.6 & 98.5 \\
\hline 屋根 & 0.9 & 100.0 & 0.4 & 66.3 & 1.7 & 91.0 & 1.1 & 90.8 \\
\hline 外壁 & 2.6 & 91.3 & 0.4 & 65.3 & 7.1 & 93.5 & 5.7 & 94.5 \\
\hline 内装 & 3.5 & 73.9 & 4.9 & 88.0 & 3.8 & 70.0 & 4.2 & 70.4 \\
\hline 開口部 & 0.0 & 0.0 & 0.0 & 2.2 & 0.3 & 0.0 & 0.1 & 0.0 \\
\hline 断熱 · 気密 & 0.2 & 74.5 & 0.5 & 94.0 & 0.7 & 66.4 & 0.4 & 78.0 \\
\hline 設備 & 1.1 & 52.5 & 0.9 & 14.1 & 1.6 & 8.5 & 1.0 & 9.1 \\
\hline 外構 & 0.2 & 0.0 & 1.3 & 64.4 & 4.4 & 3.1 & 1.7 & 2.1 \\
\hline 合計 & $\bar{~} 12.9$ & $\begin{array}{l}81.8 \\
\end{array}$ & 25.1 & $\begin{array}{ll}90.7 \\
\end{array}$ & 25.7 & \begin{tabular}{|c|}
77.7 \\
\end{tabular} & 22.1 & 84.9 \\
\hline
\end{tabular}

は住宅 B の延床面積あたりの資材重量が最大となった。これは勝手 口周りにコンクリートを敷設したためである。

\section{3 副産物重量の工事別の比較}

延床面積あたりの副産物重量を工事別に比較した結果を表 3 に示 す。なお、表中の端材の割合は副産物注1)に端材が占める割合を示し ている。基礎工事では住宅 B の延床面積あたりの副産物重量が最大 となった。これは、住宅 $\mathrm{B}$ は RC 造の車庫を有することや平面形状 が単純な矩形ではないため、型枠の端材が多く生じたためである。 躯体工事では住宅 B の延床面積あたりの副産物重量が最大となった。 これは、平面形状が単純な矩形でないため、製材と合板の端材が多 く生じたためである。屋根工事では住宅 C の延床面積あたりの副産 物重量が最大となった。これは、ガルバリウム鋼板に比べて比重の 大きい瓦の端材が生じたためである。外壁工事では住宅 C の延床面 積あたりの副産物重量が最大となった。これは、サイディングによ る端材が多く生じたためである。反対にモルタル荒壁仕上げの住宅 B は延床面積あたりの端材重量が最小となった。内装工事では住宅 B の延床面積あたりの副産物重量が最大となった。これは、平面形 状が単純な矩形でないため、石膏ボードの端材の発生量が多かった ためである。開口部工事では住宅 C の延床面積あたりの副産物重量 が最大となった。これは、サッシが宅急便で搬入されたため梱包材 のダンボールの量が多かったためである。断熱工事では住宅 C の延 床面積あたりの副産物重量が最大となった。これは、断熱材である 押出法ポリスチレンフォーム保温板の端材が多く生じたためである。 設備工事では住宅 Cの延床面積あたりの副産物重量が最大となった。 これは、設備機器の梱包材であるダンボールが多かったためである。 外構工事では住宅 Cの延床面積あたりの副産物重量が最大となった。 これは、設備機器の土台に使用するコンクリートが多量に余ったた めである。 


\section{5. 工事別の $\mathrm{CO}_{2}$ 排出量の比較}

\section{$5.1 \mathrm{CO}_{2}$ 排出量算出方法}

資材の $\mathrm{CO}_{2}$ 排出量は各資材の重量に 2006 年日本建築学会公表の $\mathrm{CO}_{2}$ 排出原単位 ${ }^{4}$ を乗じて資材の生産から流通段階までの $\mathrm{CO}_{2}$ 排出 量を算出した注 3$)$ 。なお、 $\mathrm{CO}_{2}$ 排出原単位の名称が合致しない資材に ついては、その内容に最もふさわしい資材の $\mathrm{CO}_{2}$ 排出原単位とした注 4 。

\section{2 蓄積資材注1) $9 \mathrm{CO}_{2}$ 排出量の工事別の比較}

延床面積あたりの蓄積資材注1)の $\mathrm{CO}_{2}$ 排出量を工事別に比較した結 果を図 10 に示寸。また、表 4 に本研究における住宅 $\mathrm{A} \sim \mathrm{D}$ と既往の 研究 ${ }^{17) 、 18)}$ における延床面積あたりの蓄積資材注1)の $\mathrm{CO}_{2}$ 排出量を示 す。なお、既往の研究 $1^{17)}$ の延床面積は $123.4 \mathrm{~m}^{2}$ 、既往の研究 $2^{18)}$ の 延床面積は 10 棟の平均值で $132.4 \mathrm{~m}^{2}$ である。 $\mathrm{CO}_{2}$ 排出量については 既往の研究 ${ }^{17) 、 18)}$ に記載されている資材重量に 2006 年日本建築学会 公表の $\mathrm{CO}_{2}$ 排出原単位 ${ }^{4}$ を乗じて算出した。住宅 $\mathrm{B} \sim$ 住宅 D の延床 面積あたりの蓄積資材注1)の $\mathrm{CO}_{2}$ 排出量は蓄積資材重量に比べて住宅 間に差がないことが分かる。

基礎工事では住宅 $\mathrm{B}$ の延床面積あたりの蓄積資材注1)の $\mathrm{CO}_{2}$ 排出量 が最大となった。これは、蓄積資材注1)の重量と同様、コンクリート の使用量が多いためである。躯体工事では、住宅 C の延床面積あた りの $\mathrm{CO}_{2}$ 排出量が最大となった。これは、 $\mathrm{CO}_{2}$ 排出原単位が大きい 合板の使用量が多かったためである。屋根工事では住宅 C の延床面 積あたりの蓄積資材注1)の $\mathrm{CO}_{2}$ 排出量が最大となった。これは、住宅 $\mathrm{C}$ の屋根材として使用された瓦の $\mathrm{CO}_{2}$ 排出原単位が他の住宅で主に 使用しているガルバリウム鋼板の $\mathrm{CO}_{2}$ 排出原単位よりも大きいため である。内装工事では住宅 $\mathrm{C}$ の延床面積あたりの蓄積資材注1)の $\mathrm{CO}_{2}$ 排出量が最大となった。これは、建具の使用量が多いためである。 開口部工事では住宅 $\mathrm{B}$ の延床面積あたりの $\mathrm{CO}_{2}$ 排出量が最大となっ た。住宅 $\mathrm{B}$ は $\mathrm{CO}_{2}$ 排出原単位が樹脂サッシよりも大きいアルミ樹脂 複合サッシを使用していたためである。断熱・気密工事では住宅 $\mathrm{C}$ の延床面積あたりの $\mathrm{CO}_{2}$ 排出量が最大となった。これは、蓄積資材 重量と同様、押出法ポリスチレンフォーム保温板の使用量の使用量 が多いためである。設備工事では住宅 C の延床面積あたりの蓄積資 材注1)の $\mathrm{CO}_{2}$ 排出量が最大となった。設備工事における住宅 $\mathrm{C}$ と住宅 $\mathrm{D}$ の $\mathrm{CO}_{2}$ 排出量に大きな差はないが、住宅 $\mathrm{C}$ のほうが住宅 $\mathrm{D}$ よりも 延床面積が小さいために延床面積あたりの蓄積資材注1)の $\mathrm{CO}_{2}$ 排出量 が最大となった。外構工事では住宅 B の延床面積あたりの蓄積資材 注1)の $\mathrm{CO}_{2}$ 排出量が最大となった。これは、蓄積資材重量と同様、コ ンクリートの使用量が多いたためである。

\section{3 副産物注1) $\mathrm{CO}_{2}$ 排出量の工事別の比較}

延床面積あたりの副産物注1)の $\mathrm{CO}_{2}$ 排出量を工事別に比較した結果 を図 11 に示す。延床面積あたりの副産物注1)の $\mathrm{CO}_{2}$ 排出量は住宅 $\mathrm{A}$ が $13.1 \mathrm{~kg}-\mathrm{CO}_{2} / \mathrm{m}^{2}$ 、住宅 B が $26.4 \mathrm{~kg}-\mathrm{CO}_{2} / \mathrm{m}^{2}$ 、住宅 C が $30.7 \mathrm{~kg}-\mathrm{CO}_{2} / \mathrm{m}^{2}$ 、 住宅 D が $21.2 \mathrm{~kg}-\mathrm{CO}_{2} / \mathrm{m}^{2}$ となった。工事別の副産物注1)の $\mathrm{CO}_{2}$ 排出量 が最大になる理由は副産物重量とほぼ同一となった。従って、本節 では詳細な説明を割愛する。

住宅 $\mathrm{B}$ と住宅 $\mathrm{C}$ の延床面積あたりの副産物注1)の $\mathrm{CO}_{2}$ 排出量が他の 住宅よりも大きくなった。住宅 $\mathrm{B}$ は平面形状が複雑なため、基礎工 事における型枠の端材と躯体工事における合板の端材が多く生じた。 これらの資材が該当する合板の $\mathrm{CO}_{2}$ 排出原単位が他の資材よりも大 きいためである。住宅 C は梱包が厳重な設備機器が他の住宅よりも

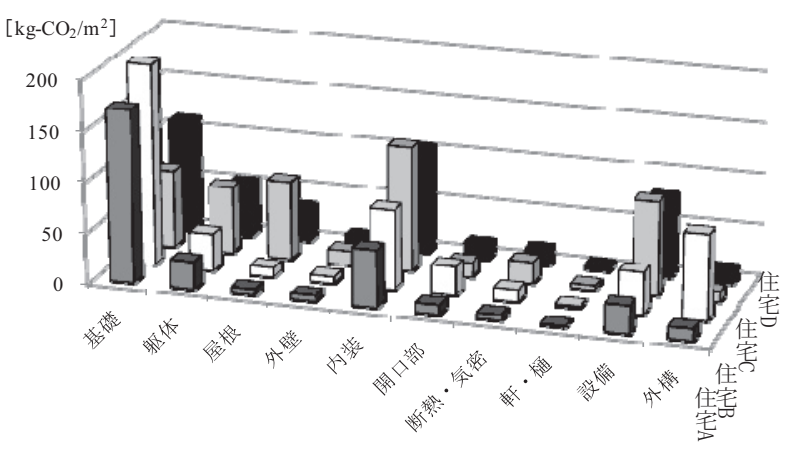

図 10 延床面積あたりの蓄積資材注 $190 \mathrm{CO}_{2}$ 排出量の比較

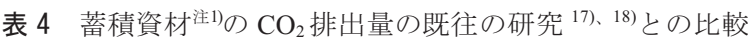

単位: $\mathrm{kg}-\mathrm{CO}_{2} / \mathrm{m}^{2}$

\begin{tabular}{|r|r|r|r|r|r|}
\hline 住宅 A & 住宅 B & 住宅 C & 住宅 D & \multicolumn{1}{c|}{$\begin{array}{c}\text { 既往 } \\
\text { 研究 } 1^{17)}\end{array}$} & $\begin{array}{c}\text { 既往の } \\
\text { 研究 } 2^{18)}\end{array}$ \\
\hline 318.8 & 497.3 & 498.1 & 440.9 & 387.4 & 570.0 \\
\hline
\end{tabular}

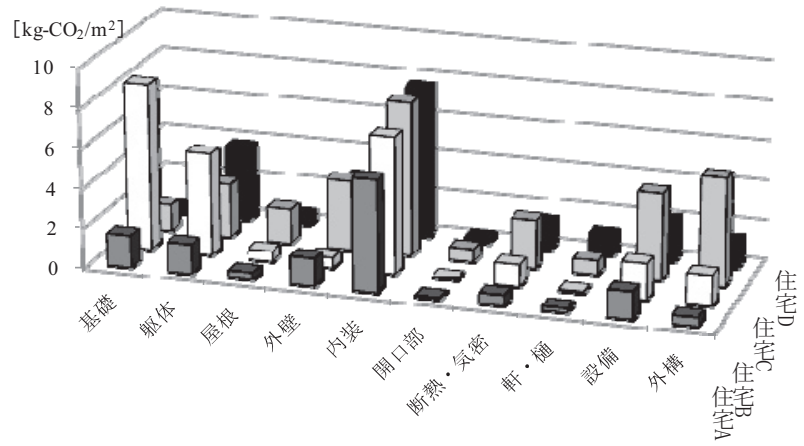

図 11 延床面積あたりの副産物 ${ }^{\text {注1) }}$ の $\mathrm{CO}_{2}$ 排出量の比較

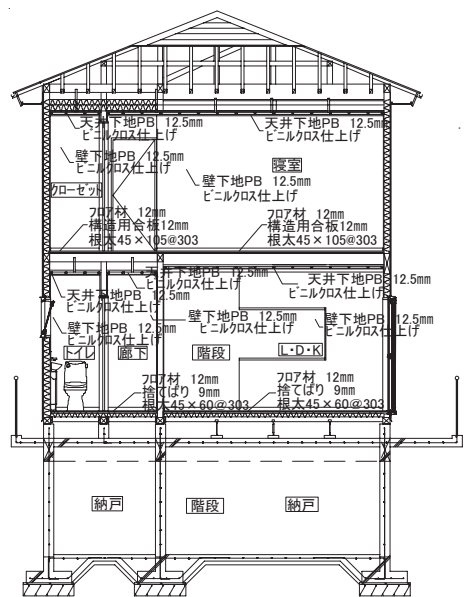

図 12 変更前の矩形図

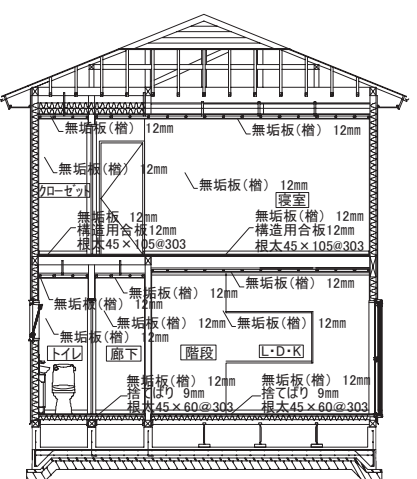

図 13 変更後の矩形図
多く、ダンボールが多く発生した。ダンボールの $\mathrm{CO}_{2}$ 排出原単位は 他の資材よりも大きいためである。

\section{6. 部位と使用資材の見直しによる建設時の $\mathrm{CO}_{2}$ 排出量削減効果}

工事別に延床面積あたりの $\mathrm{CO}_{2}$ 排出量を比較した結果、部位の見 直しという観点からは、住宅 A の 1 階部分は積雪対策として施主の 個別事情により計画、設計された部位であり、近年の積雪、降雪状 況では利用されていない空間となっているため不要と考える。また、 
使用資材の見直しという観点からは、工事別の延床面積あたりの $\mathrm{CO}_{2}$ 排出量が基礎工事に次いで大きい内装工事が対象となると考え

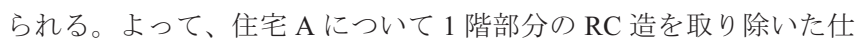
様に変更し、部位の見直しによる蓄積資材重量の削減量を算出した。 そして、 $\mathrm{CO}_{2}$ 排出量の削減量を算出した。次に、使用する内装材を $\mathrm{CO}_{2}$ 排出原単位の小さい資材に变更し、使用資材の見直しによる $\mathrm{CO}_{2}$ 排出量の削減量を算出した。さらに部位と使用資材の見直しに よる住宅 $\mathrm{A}$ の建設時の $\mathrm{CO}_{2}$ 排出量の削減量について算出した。

\section{1 部位の見直し}

住宅 $\mathrm{A} の 1$ 階部分の $\mathrm{RC}$ 造を取り除き、木造住宅工事仕様書 ${ }^{26)}$ に準じて一般的な基礎形状に变更して資材重量の積算を行った。な お小造住宅工事仕様書 ${ }^{26}$ )に記載されていない資材(結束線、スペーサ 一、セパレーター等)については、基礎工事業者からのヒアリングに もとづき資材重量の積算を行った。図 12 に現状の矩計図、図 13 に 1 階部分の RC 造を取り除いた仕様における矩計図を示す。

\section{2 部位の見直しによる資材重量と $\mathrm{CO}_{2}$ 排出量の削減量}

現状の仕様と $\mathrm{RC}$ 造を取り除いた仕様の資材重量と $\mathrm{CO}_{2}$ 排出量の 比較結果を表 5 に示寸。なお、表 5 は基礎構造の変更に伴う資材が 該当する材種のみ記載している。ここで、金属類に該当する資材は 鉄筋、結束線、スペーサーである。プラスチック類に該当する資材 はスペーサーである。コンクリート及び土石類に該当する資材は捨 てコンクリートとコンクリートである。ここで、本論文におけるコ ンクリート及び土石類に分類される資材は捨てコンクリート、コン クリート、砕石、石膏ボード、サイディング、ケイ酸カルシウム板、 セメント、タイル、衛生陶器、アスファルトフェルト等である。捨 てコンクリートとは基礎底面を平らに均したり、基礎の中心をマー クしたりするために捨て打ちするコンクリートであり蓄積資材注1) して計上している。部位の見直しとして、居住域の面積を同等に確 保しつつ、用途の無い部位を取り除いた仕様に変更することにより、 住宅 A 建設時の資材重量を $73.4 \times 10^{3} \mathrm{~kg}$ 減らすことが可能となり、 $\mathrm{CO}_{2}$ 排出量の削減量は $15.7 \times 10^{3} \mathrm{~kg}-\mathrm{CO}_{2}$ となった。現状の住宅 $\mathrm{A}$ 建設 時の $\mathrm{CO}_{2}$ 排出量は $51.7 \times 10^{3} \mathrm{~kg}-\mathrm{CO}_{2}$ であることから住宅 $\mathrm{A}$ 建設時の $\mathrm{CO}_{2}$ 排出量を $30.4 \%$ 削減することが可能となる。

\section{3 使用資材の見直し}

内装材として使用される石膏ボードやビニルクロス、複合フロー リングをこれらの資材よりも $\mathrm{CO}_{2}$ 排出原単位が小さい無垢板（梄材） に変更し、資材重量の積算と $\mathrm{CO}_{2}$ 排出量を算出した注 ${ }^{5)}$ 。なお、台 所については防火対策として石膏ボードとビニルクロスを使用した。 石膏ボードとビニルクロスについては施工面積に実測重量にもとづ く単位面積あたりの資材重量を乗じて重量を算出した。梄の無垢板 については木材活用辞典 ${ }^{199}$ に記載されている密度を使用して体積か ら重量を換算した。表 6 に各部位の面積を示す。

\section{4 使用資材の見直しによる資材重量と $\mathrm{CO}_{2}$ 排出量削減量}

現状の仕様と内装材を変更した仕様の資材重量と $\mathrm{CO}_{2}$ 排出量の比 較結果を表 7 に示す。なお、表 7 は内装材の変更に伴う資材が該当 する材種のみ記載している。ここで、木材に該当する資材は無垢板 (楢材)、複合フローリングである。金属類に該当する資材はボード ジョイントである。プラスチック類に該当する資材は塩化ビニル製 クロスである。コンクリート及び土石類に該当する資材は石膏ボー ドとパテである。ガラス類に該当する資材はボードジョイントであ
表 5 蓄積資材重量と $\mathrm{CO}_{2}$ 排出量の比較

\begin{tabular}{|c|c|c|c|c|}
\hline & \multicolumn{2}{|c|}{ 資材重量 $[\mathrm{kg}]$} & \multicolumn{2}{|c|}{$\mathrm{CO}_{2}$ 排出量 $\left[\mathrm{kg}-\mathrm{CO}_{2}\right]$} \\
\hline & 変更前 & 変更後 & 変更前 & 変更後 \\
\hline 金属類 & $3,980.2$ & $1,461.8$ & $3,856.1$ & $1,448.8$ \\
\hline プラスチック類 & 31.3 & 26.6 & 76.0 & 64.8 \\
\hline $\begin{array}{l}\text { コンクリート } \\
\text { 及び土石類 } \\
\end{array}$ & $137,805.3$ & $66,881.5$ & $23,522.0$ & $10,236.9$ \\
\hline 合計 & $141,816.8$ & $68,369.9$ & $27,454.0$ & $11,750.6$ \\
\hline
\end{tabular}

表 6 各部位の面積

\begin{tabular}{|l|r|}
\hline \multicolumn{1}{|c|}{ 対象部位 } & 面積 $\left(\mathrm{m}^{2}\right)$ \\
\hline \hline 床 & 93.8 \\
\hline 天井（台所以外の居室） & 85.2 \\
\hline 天井（台所） & 8.9 \\
\hline 壁（台所以外の居室） & 246.8 \\
\hline 壁（台所） & 15.8 \\
\hline
\end{tabular}

表 7 蓄積資材重量と $\mathrm{CO}_{2}$ 排出量の比較

\begin{tabular}{|l|r|r|r|r|}
\hline \multirow{2}{*}{} & \multicolumn{2}{|c|}{ 資材重量 $[\mathrm{kg}]$} & \multicolumn{2}{c|}{$\mathrm{CO}_{2}$ 排出量 $\left[\mathrm{kg}-\mathrm{CO}_{2}\right]$} \\
\cline { 2 - 5 } & \multicolumn{1}{|c|}{ 変更前 } & \multicolumn{1}{c|}{ 変更後 } & 変更前 & \multicolumn{1}{c|}{ 変更後 } \\
\hline \hline 木材 & 482.8 & $3,601.1$ & 614.1 & $1,148.8$ \\
\hline 金属類 & 1.3 & - & 11.8 & - \\
\hline プラスチック類 & 87.6 & 8.2 & 215.3 & 20.1 \\
\hline $\begin{array}{l}\text { コンクリート } \\
\text { 及び土石類 }\end{array}$ & $4,028.4$ & 213.6 & $5,635.7$ & 298.8 \\
\hline ガラス類 & 0.3 & 0.0 & 0.7 & 0.0 \\
\hline 化学製品 & 54.5 & 5.1 & 129.0 & 12.1 \\
\hline \hline 合計 & $4,654.9$ & $3,828.0$ & $6,606.6$ & $1,479.8$ \\
\hline
\end{tabular}

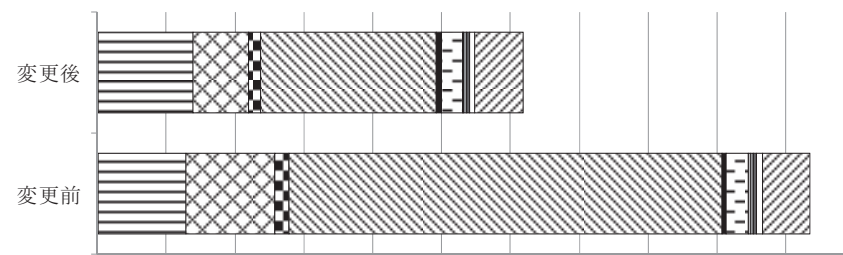

$0 \quad 5,000 \quad 10,000 \quad 15,000 \quad 20,000 \quad 25,000 \quad 30,000 \quad 35,000 \quad 40,000 \quad 45,000 \quad 50,000 \quad 55,000$

曰材

啮 コンリート及び土石類 区金属

田 プラスチック類

$\square$ 化学製品

紙類

- ガラス類

$\square$ ゴム

布・系

複合材

図 14 住宅 $\mathrm{A}$ 建設時の $\mathrm{CO}_{2}$ 排出量の比較

る。化学製品に該当する資材は接着剤である。使用資材の見直しと して、内装材を $\mathrm{CO}_{2}$ 排出原単位の小さい資材に変更することにより 住宅 $\mathrm{A}$ 建設時の資材重量を $826.9 \mathrm{~kg}$ 減らすことが可能となり、 $\mathrm{CO}_{2}$ 排出量の削減量は $5.1 \times 10^{3} \mathrm{~kg}-\mathrm{CO}_{2}$ となった。現状の住宅 A に対して $9.9 \%$ の $\mathrm{CO}_{2}$ 排出量削減が可能となる。

\section{$6.5 \mathrm{CO}_{2}$ 排出量削減効果}

1 階部分の $\mathrm{RC}$ 造を取り除き、内装材を変更した仕様による住宅 $\mathrm{A}$ 建設時の $\mathrm{CO}_{2}$ 排出量の算出結果を図 14 に示す。仕様変更後の住宅 $\mathrm{A}$ 建設時の $\mathrm{CO}_{2}$ 排出量は $30.9 \times 10^{3} \mathrm{~kg}-\mathrm{CO}_{2}$ となった。よって、 $\mathrm{CO}_{2}$ 排出 量の削減量は $20.8 \times 10^{3} \mathrm{~kg}-\mathrm{CO}_{2}$ となり、 $40.3 \%$ の削減が可能となるこ とが分かった。

\section{7. まとめ}

本論文は住宅建設時の $\mathrm{CO}_{2}$ 排出量を削減する方法を検討するため 
に、前報 ${ }^{11)}$ で報告した 4 棟の住宅に対して、工事別に蓄積資材注1) と副産物注1)の延床面積あたりの重量と $\mathrm{CO}_{2}$ 排出量を比較した。そし て、比較した結果を基に住宅建設時の $\mathrm{CO}_{2}$ 排出量を削減する方法を 検討した。結果以下のことが分かった。

1） 今後、建物仕様や施工工務店が異なる住宅について実測調查を 行い、蓄積資材注1) と副産物注1)の重量に関する実測データの蓄積に 努める必要があるが、本論文において対象とした 4 棟の住宅の実 測調査結果からは延床面積あたりの蓄積資材注 ${ }^{1} の \mathrm{CO}_{2}$ 排出量は $318.8 \mathrm{~kg}-\mathrm{CO}_{2} / \mathrm{m}^{2} \sim 498.1 \mathrm{~kg}-\mathrm{CO}_{2} / \mathrm{m}^{2}$ となった。住宅 B〜住宅 D の延 床面積あたりの蓄積資材注 ${ }^{1)} の \mathrm{CO}_{2}$ 排出量は $440.9 \mathrm{~kg}-\mathrm{CO}_{2} / \mathrm{m}^{2} \sim$ $498.1 \mathrm{~kg}-\mathrm{CO}_{2} / \mathrm{m}^{2}$ であり、延床面積あたりの蓄積資材重量に比べて 住宅間の差が小さいことが分かった。しかしながら、工事別に比 較すると住宅間に大きな差があることが分かった。

2）工事別の蓄積資材 ${ }^{2}$ (1) 副産物注1)の延床面積あたりの重量と $\mathrm{CO}_{2}$ 排出量を検討した結果、住宅 $\mathrm{A}$ が部位と使用資材の見直しにより、 建設時の $\mathrm{CO}_{2}$ 排出量削減の可能性があることが分かった。実測調 査により蓄積資材注1) と副産物注1)の重量に関する詳細なデータベ ースを構築することができため、部位と使用資材の変更による $\mathrm{CO}_{2}$ 排出量の削減量を算出することができた。部位の見直しとし て、居住域の面積を同等に確保しつつ、用途の無い部位を取り除 いた仕様に変更することによる $\mathrm{CO}_{2}$ 排出量の削減量は $15.7 \times 10^{3} \mathrm{~kg}-\mathrm{CO}_{2}$ となり住宅 $\mathrm{A}$ 建設時の $\mathrm{CO}_{2}$ 排出量を $30.4 \%$ 削減す ることが可能となることが分かった。使用資材の見直しとして、 内装材を $\mathrm{CO}_{2}$ 排出原単位の小さい資材に変更することによる $\mathrm{CO}_{2}$ 排出量の削減量は $5.1 \times 10^{3} \mathrm{~kg}-\mathrm{CO}_{2}$ となり住宅 $\mathrm{A}$ 建設時の $\mathrm{CO}_{2}$ 排出 量を $9.9 \%$ 削減することが可能となることが分かった。さらに、 部位と資材重量の見直しにより、住宅 $\mathrm{A}$ 建設時の $\mathrm{CO}_{2}$ 排出量を 40.3\%削減することが可能となることが分かった。これらの結果 は、施主の個別事情と蓄積資材重量の関係を今後検討するための 基礎資料になると考える。

本研究の今後の課題を述べる。住宅建設時の $\mathrm{CO}_{2}$ 排出量削減対策 として本論文で検討した部位と使用資材の見直しの他に、端材の削 減について検討寸る必要がある。さらに、今後は住宅 A 以外の一般 的な住宅についても用途の見直しを行い、用途の無い部位を取り除 く事による $\mathrm{CO}_{2}$ 排出量削減効果の定量化を行いたい。

\section{謝辞}

住宅 $\mathrm{A} の$ 実測調查は株式会社コロナより一部助成を受けて実施し、 住宅 B と住宅 D の実測調查は平成 18〜19 年度(社)住宅生産団体連 合会住宅関連環境行動助成事業の助成を受けて実施し、住宅 $\mathrm{C}$ の実 測調査は平成 19 年度(財)長野県科学振興会研究助成金より一部助成 を受けて実施した。調查結果の取りまとめについては平成 21 年度科 学研究費補助金(若手研究(B))「在来工法による高断熱・高気密住宅 の建設から運用までの $\mathrm{CO}_{2}$ 排出量削減に関する研究」(課題番号： 21760448、研究代表者: 高村秀紀)の一部を使用して実施した。また、 実測調査を行うにあたり、株式会社ナガノ建築サービス及び北信商 建株式会社をはじめ関係者各位に多大なる協力を得た。ここに記し て感謝の意を表す。
注1）住宅建設に要する建築資材でかつ住宅に蓄積される建築資材を本論文 では蓄積資材と定義する。端材及び梱包材は資材により廃棄される場合 とリサイクルされる場合がある為、本論文では端材及び梱包材を副産物 と定義する。

注2）本論文で羽柄材とは間柱や筋交、垂木などのプレカット以外の現場で加 工される製材と定義する。

注3) $\mathrm{CO}_{2}$ 排出量の算出式を以下に示す。

$$
\begin{aligned}
Y= & \Sigma\left(W_{i} \times I_{i}\right) \\
& Y: \text { 資材の } \mathrm{CO}_{2} \text { 排出量 }\left(\mathrm{kg}-\mathrm{CO}_{2}\right) \\
& W_{i}: \text { 資材 } i \text { の重量 }(\mathrm{kg}) \\
& I_{i}: \text { 資材 } i \text { の } \mathrm{CO}_{2} \text { 排出原単位 }\left(\mathrm{kg}-\mathrm{CO}_{2} / \mathrm{kg}\right)
\end{aligned}
$$

\begin{tabular}{|c|c|c|c|}
\hline 工事区分 & 資材 & 原単位名称 & $\begin{array}{c}\mathrm{CO}_{2} \text { 排出原単位 } \\
{\left[\mathrm{kg}-\mathrm{CO}_{2}\right]} \\
\end{array}$ \\
\hline \multirow{5}{*}{ 基礎 } & 砕石 & \begin{tabular}{|l} 
砝石 \\
\end{tabular} & 0.011 \\
\hline & コンクリート & 生コンクリート & 0.205 \\
\hline & 鉄筋 & 普通鋼小棒 & 0.941 \\
\hline & 型枠 & 合板 & 1.272 \\
\hline & 剥離材 & その他石油製品 & 0.185 \\
\hline \multirow{4}{*}{ 躯体 } & 製材 & 製材 & 0.319 \\
\hline & 集成材、合板 & \begin{tabular}{|l|} 
合板 \\
\end{tabular} & 1.272 \\
\hline & 釗 & \begin{tabular}{|l|} 
金属線製品 \\
\end{tabular} & 3.322 \\
\hline & 構造用金物 & その他の金属製品 & 3.284 \\
\hline \multirow{2}{*}{ 屋根 } & ガルバリウム鋼板 & めっき鋼材 & 1.115 \\
\hline & 瓦 & その他の建設用土石製品 & 1.399 \\
\hline \multirow{2}{*}{ 外壁 } & サイディング & セメント製品 & 0.342 \\
\hline & 珪砂 & 砂利・砕石 & 0.012 \\
\hline \multirow{3}{*}{ 内装 } & 複合フローリング & 合板 & 1.272 \\
\hline & クロス & プラスチックフィルム・シート & 2.455 \\
\hline & 石膏ボード & その他の建設用土石製品 & 1.399 \\
\hline \multirow{2}{*}{ 開口部 } & プラスチック金属複合サッシ & アルミ圧延製品 & 9.252 \\
\hline & プラスチックサッシ & 塩化ビニル樹脂 & 1.728 \\
\hline \multirow[b]{2}{*}{ 断熱 } & グラスウール & ガラス繊維・同製品 & 2.272 \\
\hline & $\begin{array}{l}\text { 押出法ポリスチレンフォーム } \\
\text { 保温板 } \\
\end{array}$ & プラスチック発泡製品 & 3.654 \\
\hline \multirow{3}{*}{ 設備 } & $\begin{array}{l}\text { 自然冷媒ヒートポンプ式給湯 } \\
\text { 器、エアコンなど }\end{array}$ & 民生用電気機器 & 6.531 \\
\hline & 塩ビ管 & プラスチック板・管・棒 & 2.346 \\
\hline & 電気配線 & 電線・ケーブル & 3.322 \\
\hline
\end{tabular}

注4）主な資材の $\mathrm{CO}_{2}$ 排出原単位は下表の通りである。なお、 $\mathrm{CO}_{2}$ 排出原単位 の名称が合致しない主な資材は表中の網掛けした資材である。

注5）楢の無垢板の $\mathrm{CO}_{2}$ 排出原単位は製材の $\mathrm{CO}_{2}$ 排出原単位を使用した。

\section{参考文献}

1) 村上ほか: 全国の住宅 80 戸を対象としたエネルギー消費量の長期詳細調査 対象住宅の属性と用途別エネルギー消費量、日本建築学会環境系論文集、 第 603 号、pp.93〜100、2006.5

2) 赤林ほか: 全国の住宅 80 戸を対象とした各種家電機器のエネルギー消費量 に関する調査研究、日本建築学会環境系論文集、第 619 号、pp.61〜 67、2007.9 3) 湯淺ほか：低負荷型ライフスタイルによる住宅のエネルギー消費量削減の 可能性、日本建築学会環境系論文集、第 642 号、pp.1019 1024、2009.8

4) 日本建築学会: 建物の LCA 指針〜温暖化·資源消費・廃棄物対策のための評 価ツール、日本建築学会、2006.11

5) 横山計三ほか：資源消費原単位を適用した低資源消費型建物の評価 産業 連関表による建築物の物量評価、日本建築学会環境系論文集、第 579 号、 pp. $81 \sim 88 、 2004.5$

6) 野城ほか: 地球環境·資源問題に考慮した溝工法選択のための原単位評価に 関する研究一型枠工法及び住宅一棟についての試算例一、日本建築学会 第 9 回建築生産と管理技術シンポジウム、pp.77〜 82、1993

7) 野城ほか：資源有効利用を考慮した住宅溝法システムに関する研究、日本 建築学会 第 10 回建築生産と管理技術シンポジウム、pp.267〜272、1994 8) 岡ほか：産業連関表による建築物の評価 その 3 住宅建設によるエネル ギー消費量、二酸化炭素排出量、日本建築学会計画系論文集、第 463 号、 
pp.75〜82、1994.9

9) 近田ほか：実態調査に基づく戸建て住宅の構成部材の環境負荷簡易推計、 日本建築学会計画系論文集、第 549 号、pp.89 93、2001.11

10) 高村秀紀、浅野良晴、岩崎圭祐 : 高床式の高断熱・高気密化住宅建設時に おける蓄積資材重量及び副産物重量の実測調査 在来工法による木造戸 建住宅の環境負荷予測に関する研究 その 1 、日本建築学会環境系論文集、 第 619 号、pp. 47〜 52、2007.9

11) 松岡澄生、浅野良晴、高村秀紀 : 設計段階と施工段階における資材重量の 比較 在来工法による木造戸建住宅の環境負荷予測に関する研究 その2、 日本建築学会環境系論文集、第 647 号、pp. 105 112、2010.1

12) Chang-U CHAE et al.: COMPARATIVE STUDY ON THE AMOUNT OF CO2 EMISSION OF BUILDING MATEREALS BETWEEN REINFORCED CONCRETE AND STEEL STRYCTURE BUILDINGS USING THE INPUT-OUTPUT ANALYSYS, The World Sustainable Building Conference,pp.1880 1883,2005.9

13) 井上ほか: 戸建て住宅の構成部材に係る $\mathrm{CO}_{2}$ 排出量の簡易推計法に関する 研究、日本建築学会環境系論文集、第 581 号、pp.103 108、2004.7

14) 小林ほか: 戸建て住宅における設備のライフサイクル $\mathrm{CO}_{2}$ 評価に関する研 究、日本建築学会計画系論文集、第 610 号、pp.83 89、2006.12

15) 横山計三 : 2000 年産業連関表による資源消費原単位の算出 産業連関分 析による建築物の物量評価（その 2)、日本建築学会環境系論文集、第 619 号、pp. 53〜60、2007.9

16) 横山計三ほか: 建築物の資源消費量の簡易計算法の提案、日本建築学会技 術報告集、第 18 号、pp.207〜211、2003.12

17) 社団法人資源協会 : 家庭生活のライフサイクルエネルギー、株式会社あん ほるめ、1994

18) 建築研究所 : 木造建築物の再資源化·資源循環化技術の開発、建築研究所 報告、No．140、2004.3

19) 木材活用辞典編集委員会: 木材活用辞典、株式会社産業調査会 辞典出版 センター、1994

20）日本規格協会 : JIS ハンドブック $2006 \cdot 8$ ・建築 I ・材料、日本規格協会、 2006

21) 山内久三郎：木造住宅の積算と見積り、理工学社、2008

22) 株式会社建築資料研究社 : 積算ポケット手帳 建築材料・施工全般 2008 前期編、 2007

23) 奥田幸司ほか：新版 図解 木造建築の積算、株式会社東洋書店、2008

24) 阿部正行 : 入門/木造住宅の積算実務-コストの考え方と計算手順、株式会 社彰国社、2005

25) はまだかんじ：改訂 4 版 木造住宅積算入門、株式会社大成出版社、2003

26) 独立行政法人住宅金融公庫 : 木造住宅工事仕様書 平成 20 年改訂、財団 法人住宅金融公庫普及協会、2008

（2010年 1 月21日原稿受理，2010年 7 月29日採用決定） 